MATEC Web of Conferences 13, 02012 (2014)

DOI: $10.1051 /$ matecconf/ 20141302012

(C) Owned by the authors, published by EDP Sciences, 2014

\title{
Effect of Syngas Moisture Content on the Emissions of Micro-Gas Turbine Fueled with Syngas/LPG in Dual Fuel Mode
}

\author{
Hussain Sadiga, Shaharin A. Sulaiman and Mior A. Said \\ Mechanical Engineering Department, Universiti Teknologi PETRONAS, Bandar Seri Iskandar, 31750 \\ Tronoh, Perak, Malaysia
}

\begin{abstract}
Syngas produced by gasification has a potential to be one of the fueling solutions for gas turbines in the future. In addition to the combustible constituents and inert gases, syngas derived by gasification contains a considerable amount of water vapor which effect on syngas combustion behaviour. In this work, a micro-gas turbine with a thermal capacity of $50 \mathrm{~kW}$ was simulated using ASPEN Plus. The micro gas turbine system emissions were characterized using dry syngas fuels with a different composition, syngas $1\left(10.53 \% \mathrm{H}_{2}, 24.94 \% \mathrm{CO}, 2.03 \% \mathrm{CH}_{4}, 12.80 \% \mathrm{CO}_{2}\right.$, and $\left.49.70 \% \mathrm{~N}_{2}\right)$ and syngas $2\left(21.62 \% \mathrm{H}_{2}, 32.48 \% \mathrm{CO}, 3.72 \% \mathrm{CH}_{4}, 19.69 \% \mathrm{CO}_{2}\right.$, and $\left.22.49 \% \mathrm{~N} 2\right)$ mixed with $\mathrm{LPG}$ in a dual fueling mode. The effect of syngas moisture content was then studied by testing the system with moist syngas/LPG with a moisture content ranging from 0 to $20 \%$ by volume. The study demonstrates that the syngas moisture content has high influence on nitrogen oxides and carbon monoxide emissions. It's found that for 5\% syngas moisture content, the NOx emission were reduced by $75.5 \%$ and $83 \%$ for Syngas 1 and Syngas 2 respectively. On carbon monoxide emissions and for same moisture content ratio, the reduction was found to be $43 \%$ and $57 \%$ for syngas 1 and syngas 2 respectively.
\end{abstract}

\section{Introduction}

Recently, a huge effort has been concentrated on using low calorific value fuels to run gas turbines for power generation. These fuels include synthetic gas which is commonly known as syngas. Syngas is mainly consists of carbon monoxide $(\mathrm{CO})$ and hydrogen $\left(\mathrm{H}_{2}\right)$ with varied levels of nitrogen $\left(\mathrm{N}_{2}\right)$, carbon dioxide, methane and water vapor. Syngas compositions can vary widely due to many factors such as: feedstock type, gasification agent and gasification method [1, 2]. The variation in compositions can effect on syngas combustion behavior and hence on the performance and emissions.

Syngas produced by coal gasification has a moisture content range of $6-20 \%$ [3], while biomass derived syngas yields a syngas with moisture content of $15 \%[1,4]$ for gasification with dry air and $31.5-40.9 \%$ for oxygen [1]. Using moist fuel to feed gas turbines has advantages in reducing the temperature inside the combustion chamber which is limited due to metallurgical constrains. On the other hand and due to the high heat capacity of the steam, using moist fuels may affect negatively on the utilization of heat released by fuel combustion because some of released heat will be absorbed by

\footnotetext{
${ }^{\text {a }}$ Corresponding author : husainsadig@yahoo.com
} 
the steam. Concerning the emissions, the presence of steam in syngas fuels has a strong effect on NOx formation. It reduces the flame temperature and therefore reduces the thermal NOx formation.

Numerous studies have investigated the influence of the steam presence in syngas on combustion and emissions [2, 4, 5]. Singh et al. [5] studied the effect of water addition on the kinetic of syngas/air combustion at elevated temperature. The study focused on flame speed measurements of syngas with various H2-CO compositions and the effect of water addition to the fuel mixture at high temperature. Delattin et al. [6] studied experimentally the combustion of wet syngas/natural gas mixtures at atmospheric condition for micro-turbine combustor. The experimental facility was supported with an external steam generator which provides the fuel mixing system with the needed amount of the steam to represent the wet syngas. The study was focused on combustor temperature, flame stability and emissions. The combustor showed stable combustion with a lower temperature and emissions levels compared to natural gas. The study was lack in giving information on combustion and emissions for the pressurized condition which is the real condition in gas turbine combustors and has a deep influence on $\mathrm{CO}$ formation [1]. Lee et al. [7] conducted an experimental investigation on the influence of $\mathrm{N}_{2}, \mathrm{CO}_{2}$ and steam dilution on the combustion performance of synthetic gas in a model of GE7EA industrial gas turbine combustor. The experiments were conducted on a $60 \mathrm{~kW}$ gas turbine combustor test facility at ambient pressure and at inlet air temperature of $380^{\circ} \mathrm{C}$. They demonstrated that the NOx emissions are decreased with as the amount of diluents is increased. They stated also that the NOx emission per unit power generation is logarithmically related only to the diluent's heat capacity.

In the current study, the effect of steam dilution on the emissions of a $50 \mathrm{~kW}$ micro-gas turbine system fueled with syngas and LPG in a dual fuel mode was investigated. The micro-gas turbine was simulated using ASPEN Plus (Advanced System for Process Engineering). The system was characterized first with dry LPG/syngas fuel then the effect of feeding the system with moist fuel was investigated in slightly pressurized combustor.

\section{Micro-Gas Turbine System Simulation}

ASPEN Plus is an appropriate tool for the simulation of small scale gas-turbine systems. Most of these systems use single stage compressor and turbine and does not include any cooling mechanism in turbine blades [8]. The gas-turbine simulation flow sheet (Figure 1) consists of an air compressor (COMPRESS), combustion chamber (COMB) and two turbines (TURB-1, TURB-2). The compressor and turbine were simulated using isentropic types in which the isotropic and mechanical efficiencies should be entered. The air compressor was driven by the first turbine (TURB-1) which mentioned by the work streamline 6 . For the combustion chamber, RGIBBS reactor was selected to simulate the reaction which occurs in the combustion chamber. The combustor heat loss was simulated by heat loss streamline Q. Table 1 shows the simulation block description.

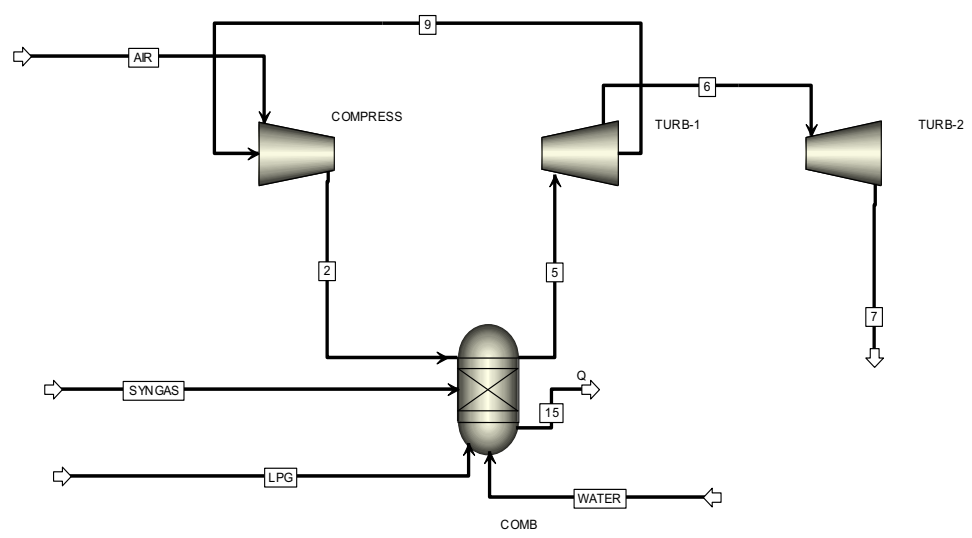

Figure 1. Flow sheet of the micro gas turbine in ASPEN Plus 
In addition to LPG, two syngas fuels with different compositions and gasification method were selected to characterize the system in a dual fuel mode. Syngas1 is produced by pre-heated air gasification of oil palm fronds (OPF) in a fixed bed gasifier. Syngas 2 is produced by co-gasification of coal and pine saw dust in fluidized bed gasifier. Oxygen rich air and steam were used as a gasification agent. Table 2 shows the compositions and the low and high calorific value of the fuels used to run the simulation. The LPG fuel used in this study is assumed to be as Malaysian standard which consists mainly of propane and butane, while the constituents with small fractions are neglected. In order to study the effect of syngas moisture content, water was added to syngas fuels in a vapor form. In order to perform the simulation and analysis for the micro gas-turbine system a number of assumptions were set and applied to the system and the working fluids, these assumptions as following:

1. All gases behave like ideal gases.

2. The ambient temperature and pressure are $25^{\circ} \mathrm{C}$ and 1 atm respectively.

3. Steady-state conditions for the system and the components.

4. Chemical reaction in the combustion chamber takes place towards the equilibrium state.

5. The air is consisting of $21 \%$ Oxygen and $79 \%$ Nitrogen.

6. The Liquefied Petroleum Gas (LPG) is consisting of 30\% Propane and 70\% Butane.

Table 1. Gas Turbine Block Description

\begin{tabular}{|c|l|l|l|}
\hline No & \multicolumn{1}{|c|}{ Block ID } & \multicolumn{1}{|c|}{ Block Parameters } & \multicolumn{1}{c|}{ Description } \\
\hline 1 & $\begin{array}{l}\text { COMPRESS } \\
\text { (Compressor) }\end{array}$ & $\begin{array}{l}\text { Isentropic Compressor (isentropic efficiency) }= \\
0.78, \text { Mechanical efficiency=95\%) }\end{array}$ & $\begin{array}{l}\text { Compress the air entering the } \\
\text { combustor. }\end{array}$ \\
\hline 2 & $\begin{array}{l}\text { COMB } \\
\text { (RGIBBS } \\
\text { Reactor) }\end{array}$ & Pressure=2 atm & $\begin{array}{l}\text { Simulate the reaction in the } \\
\text { combustor }\end{array}$ \\
\hline 3 & $\begin{array}{l}\text { TURB-1 } \\
\text { (Turbine) }\end{array}$ & $\begin{array}{l}\text { Isentropic Turbine } \text { isentropice fficiency }=0.84, \\
\text { Mechanical efficiency=95\%) }\end{array}$ & $\begin{array}{l}\text { Simulates the first stage } \\
\text { expansion which used to } \\
\text { drive the compressor }\end{array}$ \\
\hline 4 & $\begin{array}{l}\text { TURB-2 } \\
\text { (Turbine) }\end{array}$ & $\begin{array}{l}\text { Isentropic Turbine, the exhaust pressure=1.017 } \\
\text { bar (isentropic efficiency=0.84, Mechanical } \\
\text { efficiency=95\%) }\end{array}$ & $\begin{array}{l}\text { Simulates the second stage } \\
\text { expansion for power } \\
\text { generation }\end{array}$ \\
\hline
\end{tabular}

Shown in Figure 1 is the ASPEN Plus flow sheet, after gas-turbine flow sheet completed, the parameters were entered for each block and stream. The system was characterized first for a $50 \mathrm{~kW}$ thermal input using dry LPG/syngas fuel which injected separately to the combustor in a duel fuel mode with a thermal syngas heat input of $20 \%$ and $80 \%$ for LPG. The air stiochiometric was calculated for each fuel and sensitivity test was conducted on the fuel moisture content to vary the moisture content percentage in a range of $0-20 \%$ by volume.

Table 2. Syngas and LPG fuel compositions and heating value

\begin{tabular}{|c|c|c|c|}
\hline Constituents & Syngas $1[8]$ & Syngas $2[9]$ & LPG \\
\hline $\mathrm{H}_{2}(\%)$ & 10.53 & 21.62 & - \\
\hline $\mathrm{CO}(\%)$ & 24.94 & 32.48 & - \\
\hline $\mathrm{CH}_{4}(\%)$ & 2.03 & 3.72 & - \\
\hline $\mathrm{CO}_{2}(\%)$ & 12.80 & 19.69 & - \\
\hline $\mathrm{N}_{2}(\%)$ & 49.70 & 22.49 & - \\
\hline $\mathrm{C}_{3} \mathrm{H}_{8}(\%)$ & - & - & 30 \\
\hline $\mathrm{C}_{4} \mathrm{H}_{10}(\%)$ & - & - & 70 \\
\hline $\begin{array}{lll}\text { Lower } & \text { Heating } & \text { Value } \\
(\mathrm{kJ} / \mathrm{kg}) & & \\
\end{array}$ & 5,015 & 7,769 & 49,716 \\
\hline $\begin{array}{l}\text { Higher Heating Value } \\
(\mathrm{kJ} / \mathrm{kg})\end{array}$ & 5,273 & 8,282 & 45,897 \\
\hline
\end{tabular}




\section{Results and discussions}

The temperatures at different points of the system were investigated including the temperature of exhaust gas leaving the combustor, turbine inlet temperature and exhaust gas leaving power turbine at different syngas moisture content. Figure 2 shows the effect of syngas moisture content on the combustor temperature. The combustor temperature decreases with the increase of moisture content. This is due to fact that the water vapor will absorb a part of heat released by combustion. The highest combustor temperature was found to be at Syngas/LPG dry condition. For moisture content ratio of 0 $5 \%$, the effect on temperature reduction was less compared to $5-10 \%$. The increase of syngas fuel moisture content beyond $10 \%$ has no effect on reduction of combustor temperature.

The effects of water addition on nitrogen oxides (NOx) emissions were investigated for syngas/LPG fuels. For both syngas mixtures, the NOx emissions were found to decrease with the increase of moisture content. Figures 3 and 4 are showing the effect of syngas moisture content on $\mathrm{NO} 2$ and $\mathrm{NO}$ emissions respectively.

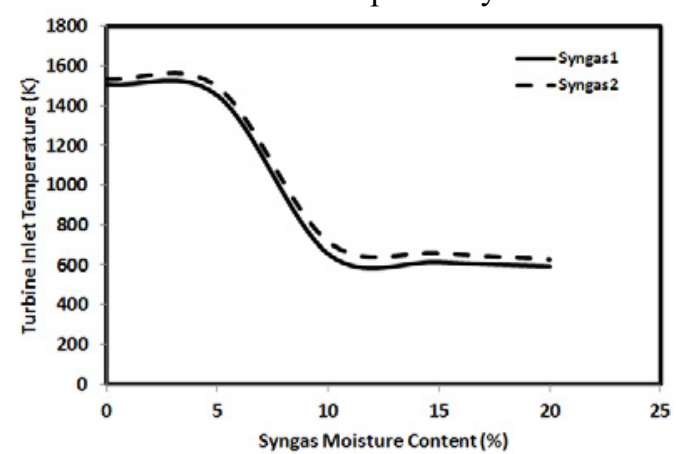

Figure 2. Effect of moisture content on combustor temperature

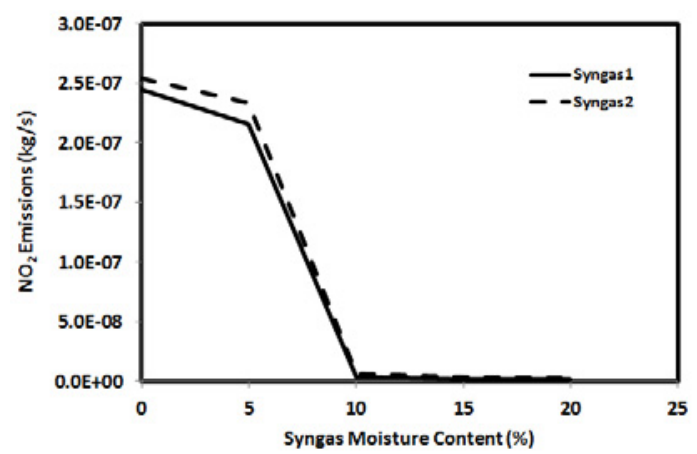

Figure 3. Variation of $\mathrm{NO} 2$ emissions with syngas moisture content

It is observed that NOx emission trends were directly affected by the combustor temperature. At dry conditions and due to the high temperatures, the nitrogen oxides emissions were in its highest levels. At 5\% moisture content the reduction of NOx emission for syngas 1 and syngas 2 were found to be $75.5 \%$ and $83 \%$ respectively which indicates the huge effect of moisture on NOx emissions. The reason for this behavior is that in the case of moist syngas, some of heat is used for water evaporation in converting water to vapor. This process decreases the flame temperature in the combustor which has negatively influences on formation of nitrogen oxides emissions. Moreover, the steam existence in the combustion chamber effects on the thermo/physical properties of the water vapor which effects on the heat transfer coefficient of the gas mixture and assists the heat transfer through the walls of the combustion chamber [11].

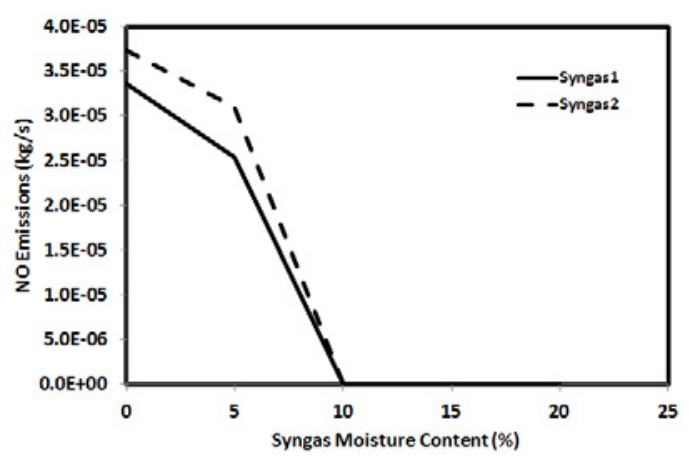

Figure 4. Variation of $\mathrm{NO}$ emissions with syngas moisture content

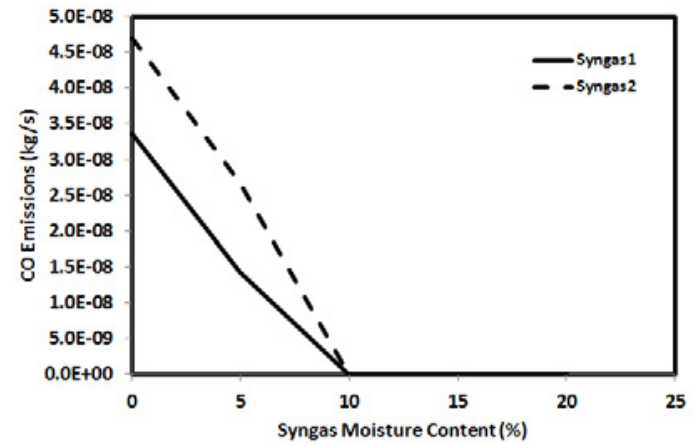

Figure 5. Variation of $\mathrm{CO}$ emissions with syngas moisture content 
The results of syngas 2 combustion showed higher nitrogen oxides emissions compared to syngas 1 . Furthermore, for moisture content less than $5 \%$, the nitrogen oxides formation in syngas 2 was less affected with the fuel moisture ratio. This is due to the higher presence of combustable constitutes $\mathrm{H} 2$ and $\mathrm{CO}_{2}$ in syngas 2 and it is influence on increasing the combustion temperatures. For moisture content ratio more than $5 \%$ the nitrogen oxides emissions reduced steeply which reflects the high influence of temperature reduction on nitrogen oxides formation.

Shown in Figure 5 is the variation of $\mathrm{CO}$ emission with syngas moisture content for the tested fuels. The highest $\mathrm{CO}$ emission levels were found to be at the dry condition. At this condition, the emission of syngas 2 was higher than syngas 2 with 29\%. This is due to the higher CO fraction in syngas 2 mixture. The $\mathrm{CO}$ emission started to reduce with the increase of the moisture content. At 5\% syngas moisture content, the $\mathrm{CO}$ emissions were less than the dry fuel emissions by $43 \%$ and $57 \%$ for syngas 1 and syngas 2 respectively. While at 10\% moisture the $\mathrm{CO}$ reaches its lowest value, beyond his point any increase of moisture has no considerable effect on $\mathrm{CO}$ emissions. This is can be explained by the effect of physical dilution of steam which resulted in the reduction of the adiabatic flame temperature. The lowering of adiabatic flame temperature resulted in a corresponding decrease in flame speed which might effect in the increase of the residence time and hence drives the combustion process towards the complete combustion.

\section{Conclusions}

In the present study a theoretical investigation was conducted on the effect of syngas moisture content on the emissions of a $50 \mathrm{~kW}$ micro-gas turbine fueled with syngas/LPG in a dual fuel mode. The micro-gas turbine system was simulated using ASPEN Plus. The investigation was carried out on the system for a thermal input of $20 \%$ syngas and $80 \%$ LPG. Two syngas fuels with different compositions with a moisture content range of $0-20 \%$ by volume were selected for this study. The main effect of syngas moisture content can be summarized as follows:

1. The combustor temperature decreased with the increase of syngas moisture content.

2. NOx and $\mathrm{CO}$ emissions were found to decrease with the increase of syngas moisture content.

3. From the results, feeding micro gas turbines with a controlled moist syngas can be used as an effective tool to control the gas turbines temperature and emissions.

\section{References}

1. T. Hasegawa, T. Nakata, and M. Sato, Journal of Engineering for Gas Turbines and Power 123, 22-32 (2000)

2. A. K. Das, K. Kumar, and C.-J. Sung, Combustion and Flame 158, 345-353 (2011)

3. P. Gupta, L. G. Velazquez-Vargas, and L.-S. Fan, Energy Fuels 21, 2900-2908 (2007)

4. J. Santner, F. L. Dryer, and Y. Ju, Proceedings of the Combustion Institute 34, 719-726 (2013)

5. Z. M. Nikolaou, J.-Y. Chen, and N. Swaminathan, Combustion and Flame 160, 56-75 (2013)

6. F. Delattin, G. D. Lorenzo, S. Rizzo, S. Bram, and J. D. Ruyck, Applied Energy 87, 1441(2010)

7. M. C. Lee, S. B. Seo, J. Yoon, M. Kim, and Y. Yoon, Fuel 102, 431-438 (2012)

8. P. M. Henderick, "An Assessment of Biomass-powered Microturbines and the Potential for Application in Rural China," Princeton University (2000)

9. F. M. Guangul, S. A. Sulaiman, and A. Ramli, Bioresource Technology 126, 224-232 (2012)

10. K. Li, R. Zhang, and J. Bi, International journal of hydrogen energy 35, 2722-2726 (2010)

11. B. Tesfa, R. Mishra, F. Gu, and A. D. Ball, Renewable Energy 37, 333-344 (2012) 